Miloš Zatkalik

UDC 78.01

Univerzitet umetnosti u Beogradu

doi:10.5937/ZbAkUm1801089Z

Fakultet muzičke umetnosti

Original scientific paper

Aleksandar Kontić

Visoka škola likovnih i primenjenih umetnosti u Beogradu.

\title{
Beyond music and beyond words: A psychoanalytic inquiry
}

Abstract. Relationships between language and music have always been lively and dynamic, from their syncretic unity in rituals, to setting text to music, verbal accounts of musical works, musicalization of literature, to abundance of linguistic and literary metaphors in discourse about music. Both language and music unfold in time; both possess a hierarchy of elements that are combined according to a set of rules.

This paper will first indicate some linguistic (primarily syntactic) concepts that inform music theory. An analogy can also be established between the Chomskyan concept of the deep structure of language and Schenkerian Ursatz.

Music, however, is not always organized along the lines of syntactic hierarchy. Music is also capable of simultaneity in a way inaccessible to language. In order to negotiate this ambiguous relationship between music and language, we invoke the psychoanalytic model of the mind. It postulates that the archaic experience of the world is associated with the auditory sphere. This auditory, pre-verbal mode of conceiving the world will gradually yield to subsequent developmental phases: the visual, and then verbal communication.

The deep structure of music is necessarily analogous to verbal structures. However, owing to its pre-verbal origin, music is also organized according to the more archaic modes of mental functioning. For instance: the precepts of logic do not apply; music allows condensation much more readily than language. This explains polyphony in music and imprecisions in parsing music flow into discrete units.

Keywords: linguistics, musical syntax, psychoanalysis, primary process 
It was not more than thirty years ago that our ethnomusicologist colleagues, when collecting folk songs in a Serbian village, found themselves in the following situation: the melody had already been transcribed, along with the first stanza of the text. What they needed was the remainder of the text, and to save time, they asked their informants not to sing, but simply to pronounce the text. The informants continued to sing. They repeated their request. Again, the response was singing. However our colleagues tried to persuade the locals to produce just the text without music, the same thing happened over and over. Within their frame of mind, no separate entities of „music"and „text" existed, only the two welded together inseparably. ${ }^{1}$

True, this mode of syncretic thinking belongs to societies we tend to call „traditional“ or „primitive.“ In contrast, we are aware of music and language as two separate activities of the human mind. Even so, the moment we start talking about speech melody, intonation, poetic meter and the like, musical images are creeping into discourse about language. From the opposite camp, a great deal of music theory and pedagogy would not exist without linguistic metaphors. Such interactions between music and language are sometimes exceedingly fruitful, sometimes dangerously misleading, but they prove that we can hardly extricate completely one from the other. Any attempt of an extensive and exhaustive survey of all aspects of these relations would go beyond our present capabilities, but we do intend to highlight some of them in the next portion of this paper.

Our particular interest resides with issues of musical syntax with its central concept of musical sentence. The term sentence (Satz) can be traced very far back, probably to the $15^{\text {th }}$ century, and has been in use with some frequency at least since Johann Mattheson. However, our analytical and pedagogical practice draws primarily on the writings of Arnold Schoenberg, who defined the musical sentence with precision and constancy (Schoenberg, 1967: 20-22) to designate a musical idea that is somehow felt to be complete and structurally independent. Schoenberg himself did not pursue linguistic analogies very far but such analogies lend themselves quite easily.

As Example 1 illustrates, music is, like language, parsable into hierarchically organized discrete units; and conversely: meaningful portions of a music flow are constructed by combining smaller units into larger. Cadential processes perform the function similar to punctuation. How these units are combined is governed by certain rules; the Chomskyan formulation whereby a definite set of elements subjected to a definite set of rules whereby an indefinite set of sentences can be generated is also a viable way of describing some important aspects of music.

1 This has been reported to us by colleague Dimitrije Golemović, Head of the Ethnomusicology Department at the University of Arts in Belgrade. 
Andante grazioso first sentence

W. A. Mozart

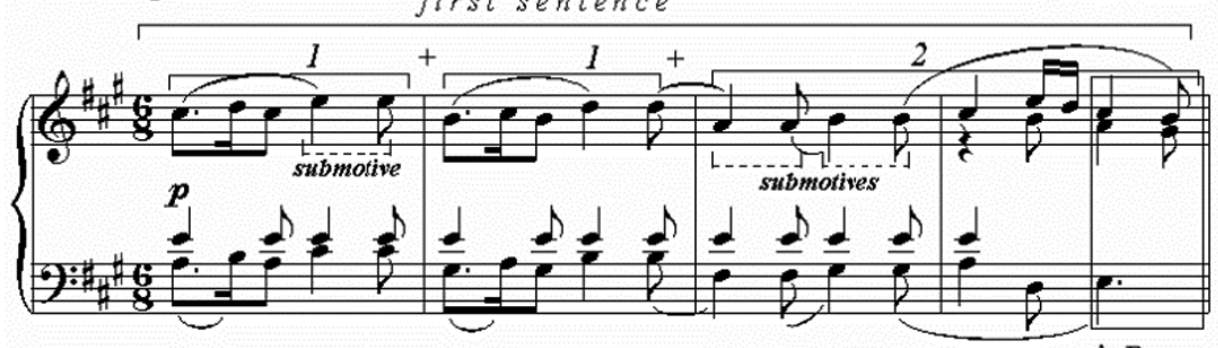

A: D

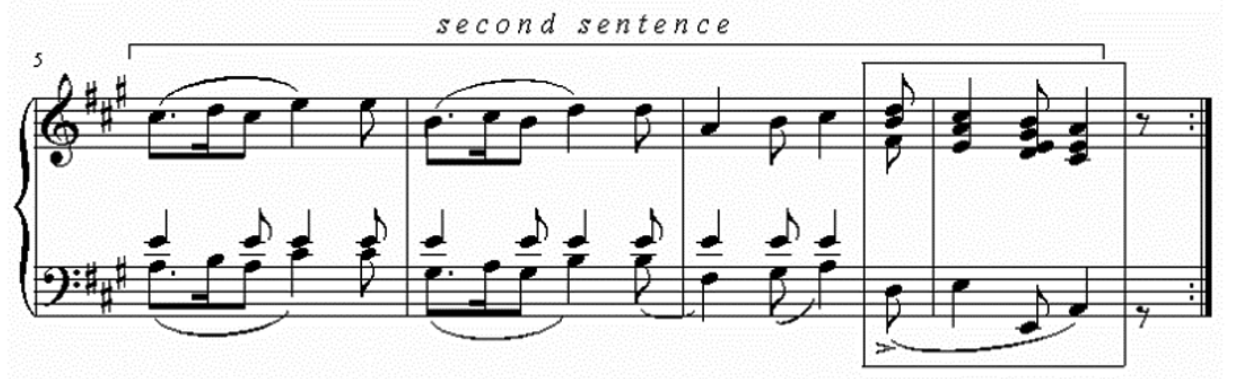

A: $\Pi 6 \quad \mathrm{~K} 6 / 4 \quad \mathrm{D} \quad \mathrm{T}$

Example 1. W. A. Mozart, Piano Sonata KV 331

As long as we are familiar with these rules of musical syntax, we are able to recognize Example 2a as musically „ungrammatical“ even if we have not actually heard the original (Ex. 2b), as much as we recognize the following sentence as incorrect: „And music now language speak about I.“
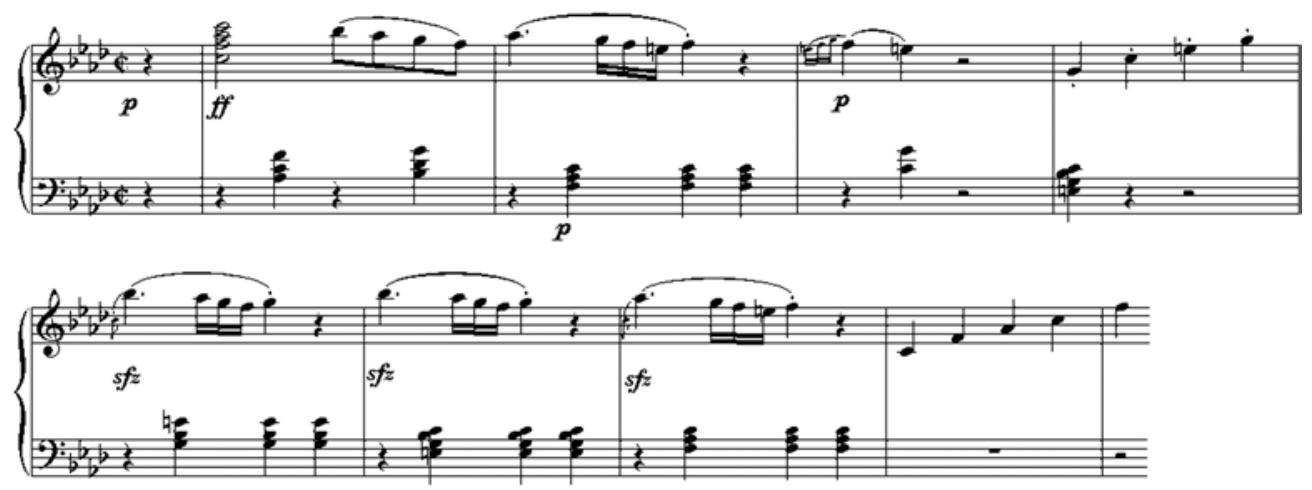

Example 2. a. L. v. Beethoven, Piano Sonata Op. 2 No. 1 

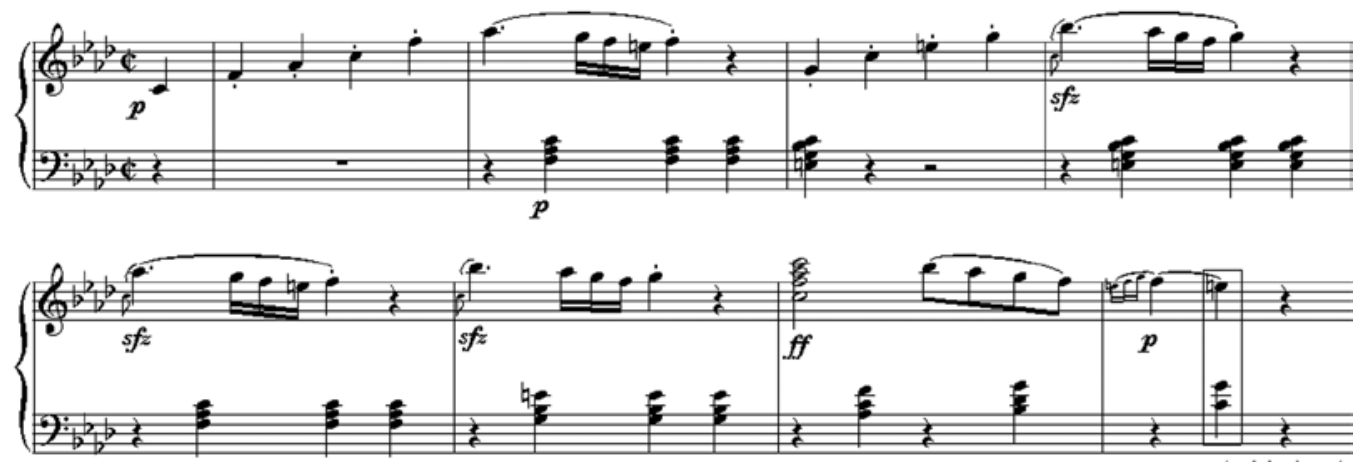

Example 2. b. L. v. Beethoven, Piano Sonata Op. 2 No. 1

Moreover, if in language we distinguish between units of first articulation morphemes as minimal signifying units - and non-signifying phonemes which are units of second articulation, a similar double articulation is arguably possible in music. Namely, an individual tone has no musical significance (except under very special circumstances); music theory generally recognizes motive as the smallest musically meaningful combination of tones.

Once introduced, this analogy with linguistics proves to be very inviting. In Example 3, the bracketed motive is obviously the smallest entity to which we attribute some kind of musical meaning (however we conceive of meaning in music). It is first transposed, then transposed again and at the same time expanded. The expansion (dotted bracket) serves to complete the phrase, but never occurs independently in the piece. The original musical motive thus behaves as a free morpheme. It later takes on a suffix; since the suffix basically performs a grammatical function without significantly altering the motive itself, it can be labeled as inflectional, and since it does not occur on its own, it is analogous to a bound morpheme. ${ }^{2}$

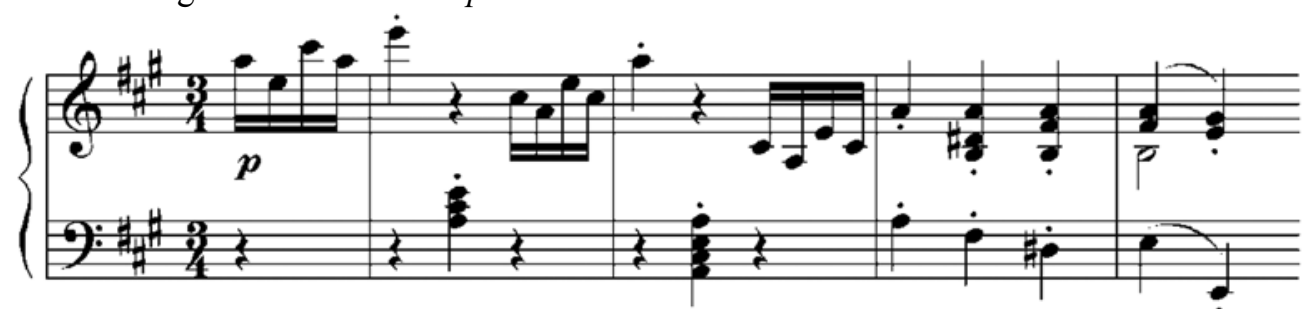

Example 3. L. v. Beethoven, Piano Sonata Op. 2 No.2, II movement

2 In Zatkalik 2004 I discuss these morphological issues at greater length, including the musical analogues of inflection and derivation. I also explore the possibilities of applying certain principles of linguistic typology in music, finding parallels between certain musical styles and isolating, agglutinative, fusional and polysynthetic languages respectively. 
To return to Noam Chomsky, it should be noted that his linguistic ideas have greatly influenced a large number of music theorists. An important theory was named „a generative theory“ and it was co-authored by an eminent music theorist and an eminent linguist (Lerdahl \& Jackendoff, 1996). They discuss at some length the elements of Chomsky's generative linguistics that they found fruitful, emphasizing also the perceptual and cognitive aspects. Joseph Swain (1997) was another major author who devoted his writings to the questions of syntax, even if he explicitly denies the concept of musical sentence. We mention these authors for the sake of illustration, any further discussion in that direction would greatly exceed the scope of this paper.

Of utmost importance for our present purpose is Chomsky's differentiation between the deep and surface structures of language; the former contains the core of semantic relationships, which are mapped onto the surface via certain transformations. As John Sloboda argues (1997: 13-22), this is analogous to the theoretical model of music by Heinrich Schenker, according to which what we actually hear is regarded as musical surface, or foreground (Vordergrund), arising from the elaboration of successive deeper layers of music. Actually, all well-made tonal music is ultimately reducible to a few types of fundamental structure, Ursatz. To anticipate the latter portion of the paper: this deep/surface dichotomy opens a psychoanalytic perspective, and points to another analogy, with the conscious vs. unconscious structures of the human mind, primary vs. secondary processes, as particularly vividly demonstrated in Sigmund Freud's analyses of dreams, distinguishing between the latent dream thoughts and the manifest dream content.

So far, we have pinpointed some fundamental similarities between language and music. However, it is through examining the ways in which music is not like language that we can perhaps learn a great deal about the both.

Discrete units did we say? Consider the following excerpt from György Ligeti's Atmosphères (Ex. 4), with its micropolyphonic texture, or perhaps the final cluster of Threnody by Krzysztof Penderecki, or for that matter most of aleatory music by composers of the Polish School, as well as a great deal of electronic music; nor do we have to restrict ourselves to the $20^{\text {th }}$ century: intricate polyphonic webs of Flemish masters would do almost as well. No human language could possibly tolerate such a blurring of boundaries between its units, such fusion of words or sentences. And whereas no meaningful use of human language is possible without sentences, here the very notion of musical sentence is collapsed. In addition, with the disappearance of tonal harmony, the cadential function is obliterated, and analogies between cadential processes and punctuation cease to be operative. 


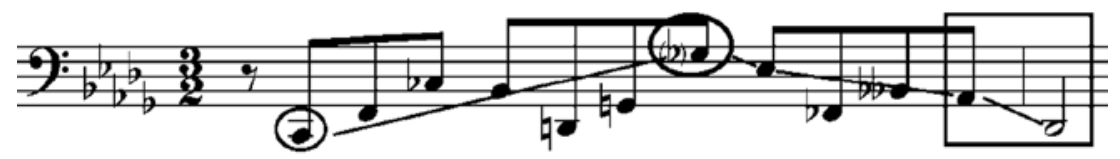

\section{Example 4. György Ligeti, Atmosphères}

At the opposite pole, we find pointillistic texture, usually associated with Anton Webern. Not only thematic units, but also the very tissue of music fragments to the point of disintegration (Ex. 5). One can hardly perceive how smaller units can be integrated into larger wholes, or identify the above mentioned double articulation or hierarchical ordering.

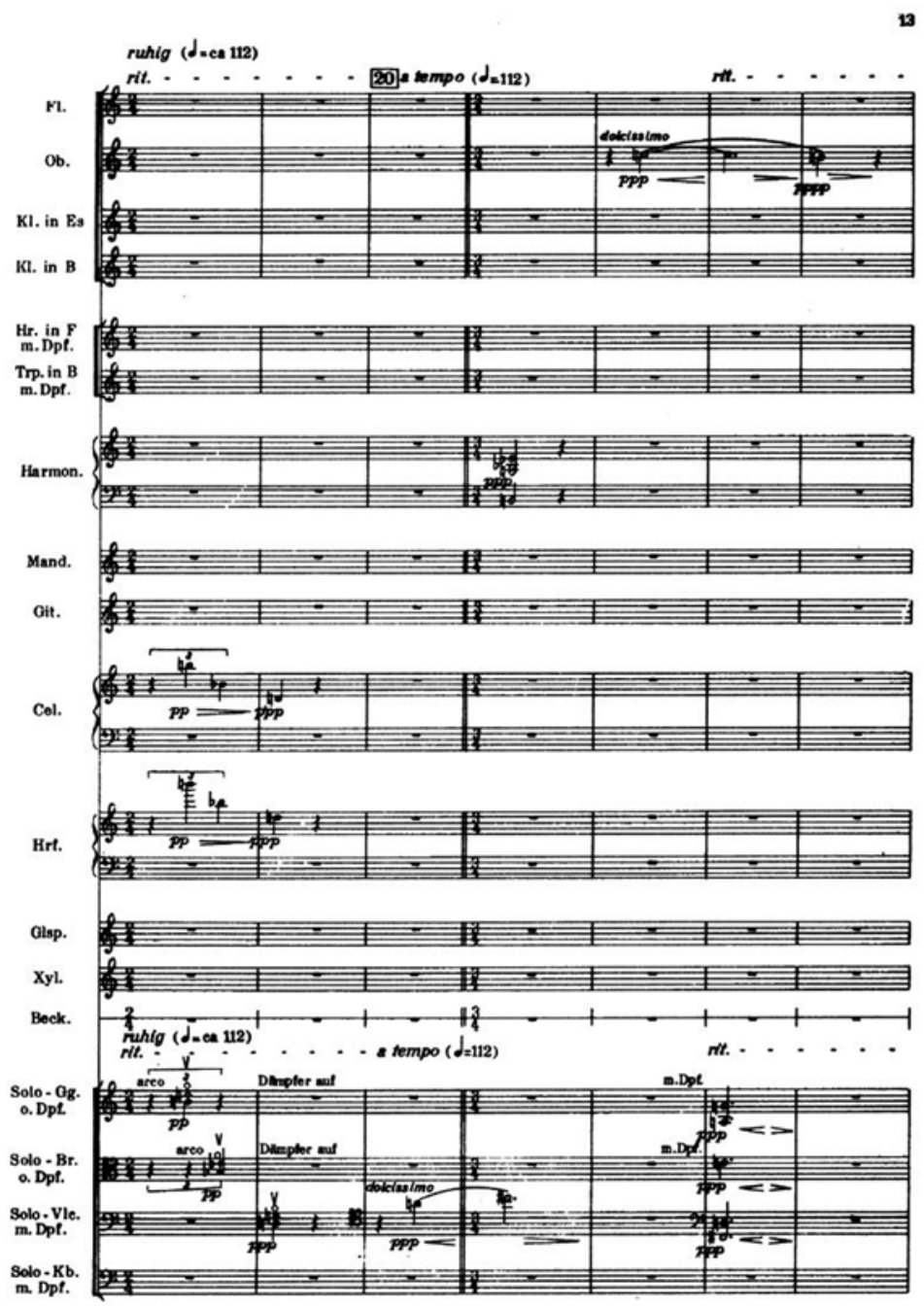

U. E. $5097 /$ U.E.12416 
Consider, further, Example 6. To group the notes the way suggested by the shaded area would seem utterly counterintuitive, and for a music theorist it clearly violates the rules of segmentation that we teach undergraduate students. Yet it is precisely what Mozart does: that same group of notes is used as a unit in the development section (Ex. 6b).

Obviously, what can and what cannot constitute a meaningful unit is rather poorly defined in music, and the segmentation of a music flow proves to be much more ambiguous than a similar process in language.

Condensation or fusion is something music achieves with facility incomparable with other forms of art. The third movement of Beethoven's Ninth Symphony is written in the form of variations on two themes (Ex. 7). The example shows the themes and then the beginning of the variation on the first. However, not only does this variation contain the notes of the first theme (notes with circles), but we can also see how certain properties of the second theme are grafted, as it were, onto it. Arguably, the two themes are condensed in a way one can hardly conceive in language. Through words, says Charlotte Balkány, following Ferdinand de Saussure, we differentiate, we separate the thing from its opposite. The statement „A“ implies ,not B“, „not C“,,not D“, etc., to say „table“, „,not chair“, „not dog“, etc. In doing so, we exclude the possibility of condensation or fusion (Balkány, 1964: 69).

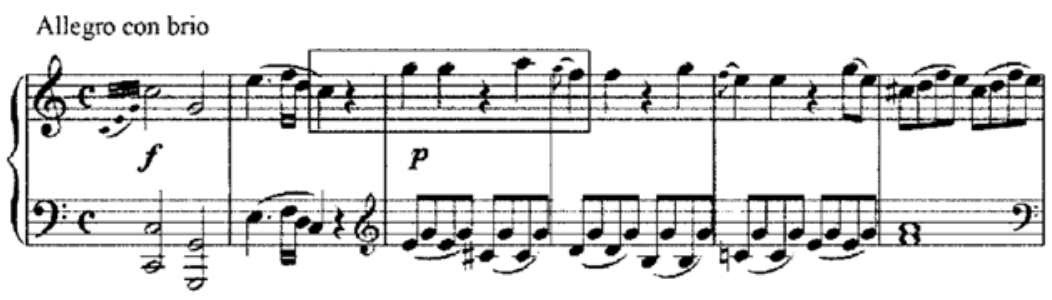

Example. 6 a. W. A. Mozart: Piano Sonata C major, KV 309, first subject
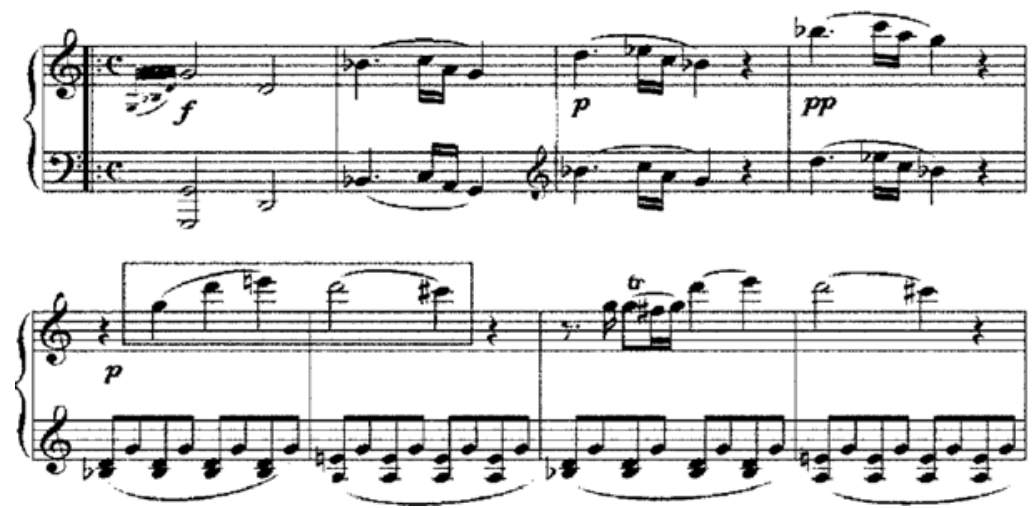

Example 6. b. Same piece, development 


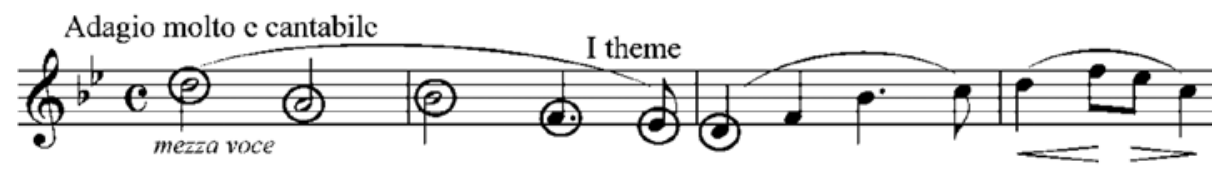

Andante moderato

II theme
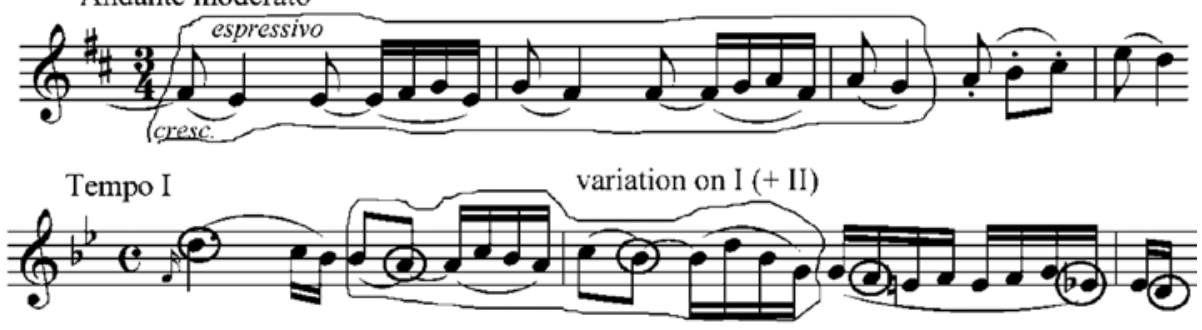

\section{Example. 7. L. v. Beethoven: Symphony No. 9, III movement}

Along similar tracks is music's predilection for simultaneity. From a simple tune with simple accompaniment to, say, elaborate counterpoint of J. S. Bach, music shows a striking ability to unfold several events at the same time. Nothing comparable exists in the verbal domain. Of no avail is Mikhail Bakhtin's concept of the ,polyphonic novel" that he coined in relation to Dostoevsky's novels: he talks about the ,plurality of unmerged voices“ (Bakthin 3) ${ }^{3}$, about ,independent verbal and semantic centers not subject to the verbal and semantic dictatorship of a single monologic style" (Ibid.: 121). According to Bakhtin, in a Dostoevsky novel there are several centers of consciousness that have not been brought to a single common denominator; characters are subjects of their own words, independent from the author himself, having their own voice and telling their own story. Let us not, however, jump to a hasty conclusion that the concept of the polyphonic novel furnishes a solid theoretical foundation for our study of musiclanguage relationships. Bakhtin himself warns against reading too much music into his ideas: „It must be noted that our comparison between Dostoevsky's novel and polyphony is no more than a vivid analogy ... the materials of music and literature being so dissimilar" (Ibid.: 13). What, indeed, would be the true simultaneity in language? Reading two or more texts at the same time? It could be rendered orally, of course; however, the semantic aspect of the words would very probably be lost. There may be some artistic merit in turning words into mere acoustic material - it has been done by both composers and poets - but this lies outside the generally accepted realm of verbal discourse. Verbal polyphony is a hopeless task. ${ }^{4}$

3 All translations from Russian are by M. Zatkalik.

4 The very challenge posed by the literary emulation of polyphonic compositions may have held some special appeal for a number of writers, such as Thomas De Quincey, Aldous Huxley, Gabriel Josipovici, Robert Pinget, Virginia Wolf, and above all James Joyce (for a more detailed discussion see Zatkalik 2015). 
Even broader principles of pitch organization, „musical languages“ as we often (inadequately) call them, can be conflated in a single musical piece, or a portion thereof, as will be illustrated by the seemingly unassuming example from Benjamin Britten's War Requiem.

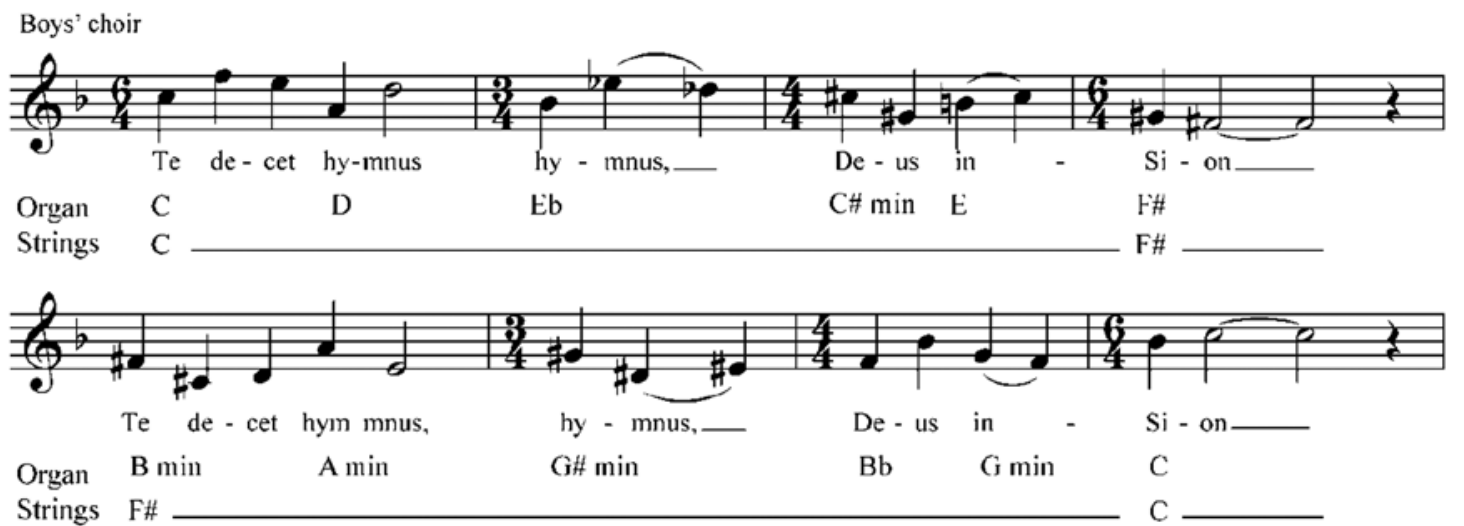

\section{Example 8. Benjamin Britten, War Requiem, Te decet hymnus}

The overall profile of the melody, and in particular the absence of overt chromaticism, suggest tonality or modality as the basis for pitch organization; the melody does not project clear tonal-functional relationships, so the modal interpretation would be more plausible. As the pitches follow one another, we soon realize that they do not repeat, and that we are dealing with a twelve-tone row. Well, not exactly. The second and third pitches but last are repetitions of the pitches already stated, and the phrase stops short of completing the full row (the missing tone is $\mathrm{G}$ ); however, on the whole, the idea of a twelve-tone row has already been driven home. This twelve-tone idea is reinforced in the next phrase: it is a transposed inversion of the first and thus conforms to the standard repertoire of dodecaphonic procedures. However, contrary to the original purpose of the twelve-tone method to be a means of obliterating pitch hierarchy, in the present case, since the initial and final pitches are the same tone $\mathrm{C}$, there is at least a hint at pitch centricity. Next, the structure of this example clearly follows the antecedentconsequent pattern of the classical tonal syntax. But the stock harmonic progression $\mathrm{T}-\mathrm{D} \mathrm{D}-\mathrm{T}$ is replaced with the tritone relationship $(\mathrm{C}-\mathrm{F} \# \mathrm{~F} \#-\mathrm{C})$. The analogy between tritonal and dominant-tonic relations is associated sometimes with Bartók, and most commonly with Scriabin, as suggested by the Russian musicologist Leo Mazel' (Мазель 1972: 493). Scriabin, however, tends to use it in octatonic contexts, of which there is not as much as a hint in the present example. All this we have inferred from the melody alone. Will the accompanying chords clarify the situation? The string chords 
seem to reinforce the harmonic profile of a departure from the quasi-tonic to the polar, quasi-dominant chord, and a return to the tonic, whereas the organ provides a touch of bitonality. What conclusions about the pitch organization can we reach based on this account? A fair conclusion would be that it is extraordinary how all these diverse principles effortlessly blend. Could we even imagine a situation in language that would be even remotely analogous? A text written simultaneously in several languages? The closest approximation we can think of would be Joyce's Finnegans Wake (and some notable works largely inspired by that novel, like Terra nostra by Carlos Fuentes), with its fusion of different words, different languages, even with characters merging into one another. By way of a briefest illustration, the Mamalujo of Finnegan is concocted out of the four Evangelists Matthew, Mark, Luke and John, and the two sentences in two different languages

My cold and melancholy male chick

Moy malyenki malchik (Russian: "my little boy")

produce a sentence in no language: Muy malinchily malchick

However, we have to bear in mind that such instances are exceptional even in literature (let alone common everyday language), and we shall try to account for them towards the end of this paper. For the time being, we will recall Suzanne Langer's explanation of the impossibility of simultaneousness in language: „The linearity of language belies the simultaneity of events. 'A killed B' has a definite successive order, which is not in accordance with what really happened. The transformation that facts undergo when they are rendered as propositions is that the relations between them are turned into something like objects" (Langer, 1958: 76).

In order to negotiate the ambiguous relationships between language and music, we invoke the psychoanalytic understanding of the mind. We shall begin with a trivial statement: music is a form of art. It engages reality in a manner not unlike a child's play. However seriously taken by the child, the play does not belong to the realm of objective reality. In psychoanalysis, this withdrawal from reality is called regression, a return to earlier stages of development, in which fantasy takes over the reality principle. But it is crucial to note that there are two kinds of regression: one is pathological, may often be irreversible, and will lead to neurotic and/or psychotic functioning: a part of unpleasant reality is denied (neurosis), or reality as a whole is denied (psychosis). As the latter falls in the realm of psychopathology, it is of no concern in this article. What, in contrast, is of vital importance is the second type of regression that the psychoanalyst Ernst Kris named „regression in the service of the ego" (Kris 1952; more recently reactualized in Knafo 2002). Pathological regression is permanent, with regressive swing moving against the will of the conscious ego; regression in the service of the ego, also known as creative regression, is purposeful and controlled by the same ego. 
Creators, by their conscious will, sever the links with the external world to listen with their inner ear to their fantasies and unconscious impulses. This is also comparable to the withdrawal from reality and entering the realm of dream that every human being undergoes. A further question now arises. When the artist willingly and temporarily regresses to earlier stages of mental functioning, to what stage of development will he regress? How „deep“ will that creative regression be along the imaginary axis of mental strata? Apparently, the regressive path is the ,shortest" for those artists who form their imagination through the verbal medium: the literary art. The visual artist will abandon the realm of spoken and written words, and, further along the regressive path, organize his fantasy by means of visual images. Finally, the musician will abandon both the realm of words and visual images, and will regress to the deepest level of the archaic psyche. This is, roughly speaking, the reverse of the developmental process. At the earliest stages of development, the world was first represented through auditory images; visual imagery is meaningfully organized at a somewhat later stage, whereas the mastering of language, the development of the verbal-conceptual apparatus is due at yet a later one (Stern 1985). In this hierarchic organization from the most archaic to the most recent, the more recent developmental layers do not obliterate the archaic ones: they exist alongside each other, and the mind is capable of fluctuating between them. It goes without saying that our insisting on the regressive aspect of artistic creation (or consumption) on no account denies the role of knowledge, craft, convention: aspects that involve a conscious, rational attitude towards reality (or, psychoanalytically speaking, highly developed secondary processes).

We have already made several references to dreams. Recalling the well known Freud's statement that the study of dreams is a royal road to the unconscious, it is through dreams that we obtain a glimpse at how this unconscious logic functions. For one, it only knows of the present tense. Furthermore, no complex sentences exist that contain relations of causality. Percepts in a dream can be condensed or fragmented, or a property of one percept can be dissociated from it and associated with another percept; simultaneous contradictions are not problematic in the least. The dreamer can be displaced to a moment in the past, while retaining a sense that everything is occurring in the present. He can converse with a person composed out of several individuals from the dreamer's reality; or dream of several persons of which the subsequent analysis demonstrates to be one and the same (possibly the dreamer himself).

All we have said so far suggests that both music and language can reside somewhere at the boundary between the conscious and the preconscious, like two sides of a coin; music being oriented towards the subject and the archaic, primary processes of the unconscious; language, in contrast, deals with the conscious, logical occurrences of reality. Similarities between them refer to the area where the two come into contact, 
and they lend credibility to such concepts as musical sentence, musical syntax; indeed of musical meaning, elusive as this notion is. They may even create a sense of their inseparability, as our ethnomusicological anecdote suggests.

Yet, music never severs ties with its archaic, preverbal roots. Analogies between the above discussed transformations in dreams and thematic processes in music have been repeatedly noted (Fisher, 1954; Friedman, 1960; Zatkalik \& Kontić, 2013, 2015), indicating isomorphism between musical structures and archaic mental structures. And if the Beethoven themes from Example 7 can coalesce, if musical texture can be so condensed as in Ligeti's micropolyphony (Ex. 4), or potentially discrete elements seamlessly fused to the point of becoming indistinguishable, this is because our unconscious mind functions in that way, because condensation is one of the chief primary-process mechanisms. If a cadential gesture, meant to establish a closure, serves at the same time to propel music forward (see, for instance, the incessant cadencing in the first themes of Mozart's piano sonatas in F major KV 332, and B-flat major KV 570), this is an instance of contradictions existing simultaneously, possible only if the precepts of formal logic are suspended. Multiplication in dreams - as when a terrifying wolf from a picture book appears as five or six wolves ${ }^{5}$-finds its counterpart in musical repetition: indeed, the amount of repetition music sustains (even requires!) would be simply absurd in language.

We can now better understand the previously mentioned example of James Joyce's Finnegans Wake with its highly condensed words and fusion of languages. Joyce's extraordinary use of language is more in accordance with preverbal primary processes pertaining to archaic mental structures - in other words, more in accordance with music - than it is with the accepted linguistic usage. Three moments ought to be highlighted: a) being a work of art, Finnegan involves a measure of creative regression, to the extent possible in the verbal domain; b) Joyce had a lasting interest in experimenting with the possibilities of employing musical constructions in his prose, which means that the regression is deeper; and c) after applying the technique of the stream of consciousness in Ulysses, his intention in Finnegan was to produce something like „the stream of the unconscious.“ Impossible, of course, but arguably, Finnegans Wake represents the ultimate regression available to language.

Many aspects of music-language relationships will perforce remain outside the confines of this paper. We regret not being able at this time to engage such areas as linguistically oriented semiotics (Raymond Monelle, Jean-Jacques Nattiez to name just two of them), or musical narrativity. There is still one issue that we would like to raise, though. A linguistic utterance signifying action can, and usually does, convey

5 The example taken from the dream of Freud's famous patient Wolf Man (Freud 1918), analyzed in relation to music in Zatkalik \& Kontic, 2013 and 2015. 
information about who performs that action. In a literary work, for instance, we usually have no problem identifying protagonists and following their actions. Now, music is a process, one cannot even imagine a music that would be totally static, but who or what performs the action? Consider the following, imaginary, but plausible description of the unfolding of a piece of music. „The first theme starts with a $\mathbf{D} 7$ resolving into submediant. The flute states the principal motive which is subsequently developed in the clarinet. After the half cadence, the movement proceeds with a bridge section. The music abruptly stops in bar (such-and-such) and the composer introduces a new theme, which we will soon hear transposed to a different key." There are no less than six grammatical subjects (bold, with corresponding verbs), plus one passive construction (underlined); no less than five or six agential categories. Who is the agent, why is it so elusive? Why do we feel there is action, but can never pinpoint the agent? ${ }^{6}$ And a related question: whose voice are we hearing? The composer's, or perhaps, as Edward Cone put it, his imaginary persona? Once again, we seek the explanation in the archaic origin of music. The archaic experience of the world implies the so-called oceanic feeling: feeling of fusion with the external world, without clear distinction between the internal and external realities, between I and not-I. With Marjorie McDonald, we observe that :

„,in the first two years of life, the child maintains [the vital emotional] tie [with parents] largely through primitive imitations and identifications with parents. To be with parents means to be one with them, a part of them... The learning of language becomes for the child a part of this pleasurable imitation and identification. But as a child learns language, he acquires a new way of communicating with his parent. The verbal communication promotes his reasoning powers. He develops a sense of separateness [italic ours] and independence“(McDonald, 1990).

Gilbert Rose, a musically competent psychotherapist, links music with interplay between primary and secondary processes; this entails a degree of fusing of subject and object (Rose, 2004: 190), echoing the original oneness with the mother (Ibid.: 20). Somehow, in music, somebody speaks or is spoken to, acts, or is acted upon and all this seems to be one and the same. Music is the realm of fusion and permeation. The domain of language - recall our earlier quotations from Balkányi and Langer - is one of individuation and separation. While it may be tempting to compare musical themes with literary characters, there are certain characteristics of music that make such comparisons seriously flawed.

6 The concept of agency without an agent originates in Maus (1988). An extensive discussion of the issues of agency and persona is found in Kivy (2009, particularly 101-157). His argument comes from the realm of philosophy, but the conclusions reached are similar to ours. 


\section{REFERENCES:}

1. Balkányi, Charlotte (1964). “On Verbalization”, International Journal of Psycho-Analysis, 45, 64-74.

2. Бахтин, Михаил [Bakhtin, Michail] (2002/1963). Проблемы поэтики

3. Достоевского. [Problems of the Poetics of Dostoevsky]. Moskva, Augsburg: ImWerden Verlag.

4. Cone, Edward T. (1974). The Composer's Voice. Berkeley, Los Angeles, London: University of California Press.

5. Fisher, Charles (1954). "Dreams and Perception - The Role of Preconscious and Primary

6. Modes of Perception in Dream Formation," Journal of the American Psychoanalytical Association, 2.

7. Freud, Sigmund (1960/1918). From the History of an Infantile Neurosis. The Standard

8. Edition of the Complete Psychological Works of Sigmund Freud, Vol. XVII.

9. Friedman, Stanley (1960). "One Aspect of the Structure of Music - A Study of Regressive Transformations of Musical Themes", Journal of the American Psychoanalytical Association, 8.

10. Kivy, Peter (2009). Antithetical Arts: On the Ancient Quarrel between Literature and Music. New York: Oxford University Press.

11. Knafo, Danielle (2002). "Revisiting Ernst Kris's concept of regression in the service of the ego in art", Psychoanalytic Psychology, 19(1), 24-49.

12. Kris, Ernst (1952). Psychoanalytic Explorations in Art. New York: International Universities Press.

13. Langer, Susanne (1958). Philosophy in the New Key. New York: The New American Library.

14. Lerdahl, Fred and Ray Jackendoff(1996/1983). A Generative Theory of Tonal Music, Cambridge, Massachusetts: MIT Press.

15. Maus, Fred Everett (1988). "Music as Drama," Music Theory Spectrum, Vol. 10, 56-73.

16. Мазель, Л. А. (1972). Проблемы классической гармонии. Москва: Музыка.

17. McDonald, Marjorie (1990). Transitional Tunes and Musical Development. In Stuart

18. Feder et al. (eds.) Psychoanalytic Explorations in Music. Madison: International University Press, 199), 79-95.

19. Rose, Glibert (2004). Between Couch and Piano: Psychoanalysis, music, art and neuroscience, London, New York: Routledge.

20. Schoenberg, Arnold (1967). Fundamentals of Musical Composition. London: Faber and Faber.

21. Sloboda, John (1997). The Musical Mind, Oxford: Clarendon Press.

22. Stern, Daniel (1985). The Interpersonal World of the Infant: A View from Psychoanalysis and Developmental Psychology. London: Karnac.

23. Swain, Joseph (1997). Musical Languages. New York and London: W. W. Norton.

24. Zatkalik, Miloš (2004). „Šta još možemo naučiti od lingvistike” [What Else Can We

25. Learn from Linguistics]; in Mirjana Živković, Ana Stefanović and Miloš Zatkalik

26. (eds.), Muzička teorija i analiza 2 - Zbornik radova sa Drugog skupa Katedre za teorijske predmete Fakulteta muzičke umetnosti u Beogradu. Beograd: Signature and Fakultet muzičke umetnosti.

27. Zatkalik, Miloš (2015). "How Can Narrative Be Musical? How Musical Can a Narrative Be?", Muzički Talas No. 43: 44-64.

28. Zatkalik, Miloš and Aleksandar Kontić (2013). "Is There a Wolf Lurking behind These 
29. Notes: The Unconscious Code of Music". In Histories and Narratives of Music Analysis, edited by Miloš Zatkalik, Denis Collins and Milena Medić, 628-644. Newcastle: Cambridge Scholars Publishing.

30. Zatkalik, Miloš and Aleksandar Kontić (2015). "Psychoanalysis and Music: Discourse about the Ineffable", Muzikologija, No. 19: 127-146.

\section{S one strane muzike i s one strane reči}

\section{Psihoanalitičko istraživanje}

Apstrakt: Odnosi između jezika i muzike su odvek bili živi i dinamični, od njihovog sinkretičkog jedinstva u ritualima, do komponovanja muzike na određeni tekst, verbalnog prikaza muzičkih dela, muzikalizacije književnosti, do obilja lingvističkih i književnih metafora u diskursu o muzici. I jezik i muzika se odvijaju u vremenu; oboje poseduju hijerarhiju elemenata koji se kombinuju po utvrđenim pravilima.

Ovaj rad će najpre ukazati na neke lingvističke (prvenstveno sintaksičke) koncepte koji prožimaju muzičku teoriju. Može se uspostaviti i analogija između koncepta dubinske strukture jezika Čomskog i Šenkerove osnovne strukture (Ursatz).

Muzika se, međutim, ne može uvek opisati kao hijerarhijski organizovana sintaksička struktura. Muzika je takođe sposobna i za simultanost na način nedostižan jeziku. Da bismo mogli da pomirimo ovakav dvosmislen odnos između muzike i jezika, prizivamo u pomoć psihonalitički model uma. On pretpostavlja da je arhaično iskustvo sveta povezano sa auditivnom sferom. Ovaj auditivni, preverbalni način poimanja sveta će postepeno voditi ka sledećim razvojnim fazama: vizuelnoj, a potom i verbalnoj komunikaciji.

Dubinska struktura muzike je svakako analogna verbalnoj strukturi. Međutim, zbog svog preverbalnog porekla, muzika je organizovana i po starijim principima mentalnog funkcionisanja. Na primer, pravila logike nisu primenjiva; muzika dopušta kondenzaciju mnogo lakše nego jezik. Ovo objašnjava polifoniju u muzici i nepreciznost u raščlanjivanju muzičkog toka u zasebne jedinice.

Ključne reči: lingvistika, muzička sintaksa, psihoanaliza, primarni proces 